\title{
7 New Labour, school effectiveness and ideological commitment
}

\author{
Robert Archer
}

\section{Preamble}

As Bhaskar (1989:1) argues, we need to take philosophy seriously because it underwrites both what constitutes science and knowledge and which political practices are deemed legitimate. At present, the field of educational research internationally is witnessing a pragmatist trend, whereby practical education research is carried out without reference to ontological and epistemological concerns. For David Reynolds, a leading UK school effectiveness academic, '[p]recisely because we did not waste time on philosophical discussion or on values debates, we made rapid progress' (1998:20). Equally, for Teddlie, '[t]he orientation of many in the US is to do rather than to reflect [...] In reality many practitioners are currently interested in what could work at their school [...rather...] than in ruminations about social inequalities associated with different socio-economic classes' (Teddlie and Reynolds 2000:27). The purpose of this chapter is not only to reclaim critical realist social philosophy for educational research, but also to reclaim reality from the positivist and statistical methodology that underpins School Effectiveness Research (SER) and to make clear the difference that realism makes by virtue of its critical explanatory power in unmasking the ideological nature of SER and its adoption by New Labour.

\section{Introduction}

In commenting upon New Labour's education policy, Gillborn and Youdell (2000:31) point to its technicist and deeply regressive nature (see also, inter alia, Angus 1993; Ball 1990; Gewirtz et al. 1995; Hill 1999; Morley and Rassool 1999; Scott 2000; Thrupp 1999; Archer 1999a, 2002). They note that one of Labour's first 'innovations' was to establish within the Department for Education and Employment (DfEE) the Standards and Effectiveness Unit. The title is significant since the repetition of 'standards' underscores the continuity with Conservative discourse, but the second part-the effectiveness part-is equally important: 
The unit's head, Professor Michael Barber, is a leading writer on school effectiveness and improvement, a prominent and growing school of work that has attracted considerable controversy [...] In particular, sociological critics have attacked the naïve basis of many studies that seek to identify (recipe-style) the elements that predispose a school towards being more or less 'effective'.

(Gillborn and Youdell 2000:32)

Indeed, SER has been strongly criticised for its ideological congruence with New Labour's consolidation of New Right education policies enacted in the 1980s and 1990s. Goldstein and Woodhouse's (2000) recent contribution represents one of a small number of attempts by SE researchers to deny or play down the charge of ideological commitment and/or New Right association, while at the same time recognising the limitations of some of the research within the field itself. Such engagement with critics of school effectiveness is long overdue and welcome. However, it is argued here that the counter-critique remains fundamentally flawed. The charge of New Right ideological commitment is reiterated. It is argued that the positivism of the Office for Standards in Education (OFSTED), statistical modelling, the lack of theorising within SER and the generic espousal of pragmatism resonate strongly withand contingently buttress-the individualist social ontology of neo-liberalism that underpinned the quasi-marketisation and commodification of education in England and Wales. ${ }^{1}$

Reynolds has admitted that '[s]chool effectiveness has sung the policymakers' tune in its emphasis upon how schools can make a differenceindeed we wrote their words' (1998:20). Yet, as Thrupp (2001) argues, nowhere in the SE counter-critiques can be found examples of SE researchers not just providing research support for, but actually implementing, the agendas of neo-liberal/managerialist governments in various roles around the globe. $\mathrm{He}$ notes that in the UK, for example, SER proponents are involved in developing, promoting and evaluating New Labour's educational reforms. Goldstein and Woodhouse are also cognisant of the quasi-umbilical relationship with past and present UK governments. In fact, they recommend that SER should rename itself as Educational Effectiveness precisely in order to separate SE research from government influence.

Furthermore, Teddlie et al. (2000:105-15) present growing reservations within the SE community about the use of multi-level modelling because of, inter alia, its excessive scientism, accompanied by a discussion of the modelling now required. In short, they argue that, ultimately, the high hopes held for multilevel modelling have not been realised. This is a welcome move away from Mortimore and Sammons' riposte to SE critics that 'the use of MLM [multilevel modelling] has enabled us to tease out the impact of a school on pupils with quite different educational backgrounds and to make the case on their behalf' (1997:185). Indeed, they concluded then that '[m]ore complex models are needed to reflect the complexity of the educational processes [...] In general, 
we seek to use a range of quantitative and qualitative methods' (1997:186-7). What is conspicuously absent here is any discussion of modelling's inherent lack of explanatory power to account for the complexity of educational processes and outcomes. There is no serious attempt to assess the extent to which statistical modelling adequately represents the complexity of social reality. SE researchers who adopt statistical methods do not ask what real objects and processes must be like for mathematical representations of them to be adequate. The emphasis on data-on how data are used, how much they should be used, how reliable they are, and so on-detracts from any exploration of social ontology and explanatory methodology. In other words, when problems are acknowledged, there is no exploration of the conceptual and metaphysical problems implicit in the use of statistics.

For Goldstein and Woodhouse, the issue is not about statistical modelling per se but about how well it is used by SE researchers:

Statistical modelling, of course, is only as good as the data which it attempts to model. It is also often the case that such models oversimplify reality to the point of distorting it and producing misleading inferences. To point to specific inadequacies, however, or to list inappropriate uses of such models does not invalidate them per se. Statistical modelling of a complex kind can provide insights, and unexpected relationships.

$(2000: 359)$

This exemplifies my point about the primacy accorded to data, rather than to social ontology and explanatory methodology. ${ }^{2}$ Goldstein and Woodhouse comment that

the future health of SE research depends on a collective recognition by the community that all is not well; that there is a clear need to come to agreement on separating the good from the bad and that there is a need to move onto a sounder methodological basis, which among other things, will require the collection of different kinds of data. The SE community would also do well to be more receptive and less defensive about its critics, and to avoid the kinds of superficial responses we have discussed above. Likewise, there is a need for some critics to demonstrate a deeper understanding of SE research.

$(2000: 360)$

Indeed, the authors are concerned about "the failure of the "qualitative" critics properly to understand the nature of quantitative techniques', which, they argue, 'is quite serious since these critics do have valid points whose force is often dissipated through lack of proper understandings of the nature and substance of quantitative models' (2000:359). The crucial issue here centres on the explanatory utility of statistical modelling. The issue for critics like myself is that the use of modelling as an aid to causal explanation is problematic since its language is 
acausal and astructural. It is unable, among other things, to distinguish causal from accidental relations. Indeed, the concept of variable, for example, is indifferent vis-à-vis causal explanation: variables can only register change, not its cause. The minute we start to ignore causal properties and powers it is easy to see why New Labour's educational policy-making can so readily argue for 'zero tolerance', since prior conditioning by structural and cultural properties is erased at a stroke (or held in abeyance).

This leads me to my final point. The neo-liberal restructuring of education presupposes a social ontology that is unstructured and undifferentiated. The argument for ideological commitment on the part of SE statisticians in particular derives from the contingent compatibility between the secreted social ontology of statistical methods and the atomistic social ontology of neo-liberalism. Let's be clear here: I am not suggesting that statistical modelling necessarily entails neo-liberalism. The argument is that the inability of statistics to distinguish between contingent and necessary relations and thus to incorporate the stratified nature of social reality resonates with the social ontology of neoliberalism. As Sayer puts it:

The blindness of mathematics to internal relations and emergence encourages [...] the belief that complex actions can be treated as reducible to some simple combination of simple behaviours which in turn are regular responses to set stimuli, as if each stimulus and action had the same meaning regardless of context.

$(1992: 200)$

Sayer's argument is that individualistic theories that portray society as a structureless aggregate of externally related individuals resonates more easily with the use of quantitative methods. Thus Goldstein and Woodhouse are correct to argue that statistical models 'certainly have no inbuilt requirement for any particular managerial structure' (2000:355), but they cannot see that they resonate strongly with the neo-liberal restructuring of education. The relationship is one of contingent compatibility, not necessary concomitance, between statistical methods and the New Managerialist/neo-liberal restructuring of education in England and Wales.

To be fair, Goldstein and Woodhouse are aware of the ideological usurpation of SE research by past Conservative and New Labour administrations. However, they do not accept the charge of New Right association. While their recognition of the role played by SER in New Labour's education policy is welcome, it is important to reiterate the charge of right-wing ideological commitment. New Labour's modernisation project; the growing emphasis upon 'what works'; the lack of theorising within SER; statistical modelingall share the same social ontological bed, which denies the irreducibility of society to individuals. What Goldstein and Woodhouse have yet to acknowledge is that statistical modelling's implicit social ontology renders it susceptible to right-wing appropriation. 


\section{New Labour, New Right: the case of education}

As Powell notes, it is possible 'to point to a number of areas where New Labour exhibits a large degree of policy continuity with the Conservatives, or is even going beyond the Conservatives' (1999:284). In the case of education, for many commentators New Right consolidation has occurred. The support that derives from SE research for neo-liberal and managerialist policies has been widely noted (Angus 1993; Dale 1992; Whitty et al. 1998; Lauder et al. 1998; Olssen 2000; Thrupp 1999; Archer 1999b). However, the extent to which there is isomorphism between the New Right and New Labour is contested. As Clarke et al. (2000) note, much effort has already been spent on trying to identify the distinctive political configuration of $\mathrm{New}$ Labour, which has been dominated by questions of difference and continuity in relation to 'Old Labour' (or social democracy) and to the New Right (or Thatcherism and neoliberalism). However, in the case of education I would argue that there is isomorphism. As Morley and Rassool (1999) point out, while New Labour has reinserted the concept of disadvantage via the creation of Education Action Zones, the implicit assumption remains that such schools can perform independently of contextual constraints. This is consistent with the atomistic social ontology of OFSTED, much of the SE literature, and neo-liberalism, which in turn provides ideological legitimation for $\mathrm{New}$ Managerialism in education and concomitant work intensification.

As Fergusson succinctly puts it:

On the face of it, New Labour in education, as in other spheres, has adopted wholesale most of the premises of neoliberalism, many of its objectives, and almost all of its methods of delivering them. Competition, choice and performance indicators remain the unchallenged totems of policy, not in overt policy statements but simply by being left unchallenged by New Labour reforms. Structurally, little that is fundamental is changing in the ways in which schools and colleges are run. Markets and managerialism hold sway [...] Only the rhetoric of what schools and colleges can and should produce changes [...] The point of difference [between New Right and New Labour] is not whether schools should be better, but which ones should be made better first.

$(2000: 203)$

I would add here that the imposition of baseline assessment and national targets represent an extension of neo-liberalism. Furthermore, Fergusson notes that New Labour's commitment to modernisation includes a supplementary set of priorities, namely the drive towards inclusionary policies, the idea of stake-holding and efforts to secure democratic renewal, which 'all assign a new priority to the social consequences of modernization, so long as they are accompanied by risk sharing and responsibilization' (2000:205). Inclusion here means adopting middle-class values and practices within an individualist and competitive framework. Equally, 
'responsibilization' is individualist. As Fergusson rightly argues, parents are made implicitly responsible for their children's education, 'as the new discourse shifted the boundaries of where the state's responsibilities stopped, and parents' began' (2000:209).

Freeden (1999:44) argues that the ideological amalgam of New Labour includes liberal, conservative and socialist components as well as ideational additions from the US. For him, New Labour ideology is not identical with any one of the latter categories. He rightly argues that ideologies do not have to be grand narratives nor closed, doctrinaire and abstract systems. It would be useful here analytically to distinguish between ideas (or what Archer (1995) calls the 'Cultural System') and what people do with them (at the level of socio-cultural interaction). Ideas remain ideas until used or activated by social actors: it is the social use of specific ideas that may (or may not) be ideological. By analytically separating out ideas and their use, one can account for the contradictions that exemplify New Labour (and past Conservative) social policy. Thus, for example, while in the abstract (cultural systemic level) neo-liberal ideas disclaim the stratified nature of social reality, practically (at the sociocultural level) actual markets require institutions and organisations that are irreducible to individuals, as we shall see. Indeed, quintessential to New Right discourse is the out-and-out denigration of bureaucracy. As advocates of entrepreneurial governance often appear incapable of conceptualising public bureaux in anything other than negative terms, they cannot imagine what sort of positive role those bureaux might be performing' (DuGay 2000:67). The point here is that while bureaucracy may be inefficient and inhibit innovation it cannot be avoided. Both private and public organisations need a significant degree of bureaucratisation if they are to cope with large throughputs of information and material.

\section{Ideology, Hayek and the nature of 'the market'}

As Bhaskar (1989:87) argues, designating a set of ideas as 'ideology' is only justified if they can be explained as well as criticised, which involves being able to say why the ideas or beliefs concerned are false. This section provides the backdrop to the widespread acceptance of neo-liberal ideas, as propounded in particular by Hayek. It also provides an explanation of the falsity of neo-liberalism via transcendental argumentation. The ideology of the 'free' market is laid bare; this in turn enables the charge of ideological commitment against SER proponents developed in the next section, for the positivist impulse of the latter is contingently congruent: both positivism and neo-liberalism are transcendentally false and ideological.

Jonathan (1997) has argued convincingly that the populist appeal of the 'New Right' agenda for restructuring-or the quasi-marketisation of-education stems from the liberal promises of equality that were made following the 1944 Butler Act. She argues that recent New Right attacks on education tapped a reservoir of popular unease. Such unease was not unsurprising since, 'despite reformist measures over three decades, the post-war education project of individual 
emancipation for each and simultaneous social progress for all had failed to deliver to many what they had hoped for from it' (Jonathan 1997:57). Indeed, it was the failure of Keynesian social democracy that resonated well with 'liberal' thinking that dates back further than the oil crisis. I have deliberately placed scare quotes around liberal, since neo-liberalism, while anchored in eighteenth-and nineteenthcentury premisses about the danger of well-intentioned paternalism leading to authoritarian coercion, fails to engage with unresolved questions about the interdependence of agency in the social world. Thus, to Jonathan,

nineteenth-century liberal niceties about the relation of the individual to the social are conspicuous by their absence in the pronouncements not only of politicians of New Right persuasion [...] but also in some philosophical writing and in the exhortations of 'opinion-formers' in right-wing 'think-tanks'. The claim that neo-liberalism represents the eclipse of politics by economics may seem superficially surprising when apologists are typically keen to adopt the mantle and invoke the authority of the early liberals, but that invocation is seriously misleading

Part of the systematisation of the 'New Right' philosophy places a premium on a (potentially rewarding) search for congruent ideational items. Hence the selective use of ideational items from Mill, Hume, Smith et al. during the 1980s by such organisations as the Centre for Policy Studies, the Adam Smith Institute and the Institute for Economic Affairs. The Centre for Policy Studies was founded by Margaret Thatcher and Keith Joseph and quickly became a focus for the ideas of such right-wing thinkers as Milton Friedman and F.A. Hayek. The underlying theme for the ideas systematised by sections of the New Right was the alleged superiority of market mechanisms and the need for sound money. Such cultural embroidery was carried out against the backdrop of the Black Papers, of which the last was published in 1977.

[Henceforth] the discursive cudgels of the conservative educational offensive were taken up by a variety of related and overlapping New Right agencies and groups [...] What makes them markedly different from the rather informally produced Black Papers is the degree and sophistication of their organisation and strategies for dissemination [...] By the 1980s [...] neoliberal texts, particularly the work of Hayek, and monetarist theories like those of Friedman, are paraded as a basis for social and economic policy making.

(Ball 1990:34-5)

However, as Gamble (1988) notes, the call for the restoration of sound money has been the New Right's centrepiece and is the issue on which the New Right first made a major impact. Despite continuing disagreement about the nature of the economy, the widening of divisions between competing macro-economic 
perspectives and the undermining of the theoretical underpinnings of monetarism, it was the marked deterioration in economic performance of the 1970s that accounts for the New Right's ascendancy. Monetarists argue, inter alia, that the control of inflation should be prioritised, irrespective of any increase in unemployment. New Right economics decries state intervention because it is held that administrative and bureaucratic structures are inherently inferior to markets as a means of allocating resources. With regard to public expenditure and taxation, New Right economists assert that market solutions would in every case be superior to the established public provision. At the same time, there evolved the contribution of 'public choice theory', which argued against the notion that public bodies are disinterested and enlightened, while putting forward the view that private individuals and companies are self-interested and avaricious. The argument here is that the pursuit of self-interest by private bodies is licensed by the existence of a competitive framework of rules that does not exist in the public sector. Consequently, many in the New Right concluded that 'markets were much superior to democracy in representing and aggregating individual choices. It was only a short step to arguing that democracy needed to be hedged around with restrictions to ensure that it did not permit encroachments upon the private sphere' (Gamble 1988:52).

\section{Hayek's catallaxy: the denial of social structure}

The key thinker of the neo-liberals is Hayek. The term 'neo-liberalism'-as has occurred with the generic 'New Right'-is employed as a portmanteau, which embraces Friedman's economic liberalism, Nozick's libertarianism (the advocacy of the minimal state) and Hayek's Austrian economics. Hayek lends support to the sui generis properties of the division of labour. He distinguishes between 'catallaxy' and 'economy'. His conception of economy is a restricted one, referring to clusters of economic activities that are organised for a specific purpose and have a unitary hierarchy of ends, in which knowledge of how to achieve ends is shared. A catallaxy, on the other hand, has no unitary hierarchy of ends, but a mass of innumerable economies without a specific purpose. As Hayek has famously pointed out, it is the product of spontaneous growth as opposed to design. One of Hayek's central arguments, contra state socialism, is that the catallaxy eludes regulation by central control. This is because of the extraordinary division of knowledge immanent in any advanced industrial economy. Thus the fundamental economic problem is not calculational but epistemological; namely, how to coordinate the actions of innumerable agents without the possibility of any adequate centralised knowledge of their needs and resources. Consequently, competition operates as a discovery procedure and the main role of markets is in generating information through the price mechanism as to how economic agents ignorant of each other may best attain their equally unknown purposes (Sayer 1995).

The salient point, then, is that the complex and evolutionary nature of the catallaxy renders its qualities unknowable to any single mind or organisation. 
Hayek correctly takes to task the socialist vision of a collectively controlled and planned advanced economy-a 'fatal conceit', which he terms 'constructivism'. As Sayer (1995) points out, many Marxist positions have failed to acknowledge the fundamental difference between running a technical division of labour for producing a particular type of commodity and coordinating a social division of labour involving millions of different commodities, thousands of enterprises and billions of customers. This is not to license chaos, for although catallaxies are unplanned they are ordered. Yet, for Marx, the only good order 'must be the product of conscious collective purpose, a Hegelian legacy of humanity rising to consciousness and control over itself [...] Marx is resistant not only to actions having bad unintended consequences, but to unintended consequences per se' (Sayer 1995:76). However, Hayek adopts the extreme counter-position to Marx. In brief, he reasons that because unintended consequences of actions are central to the functioning of catallaxies, one must not intervene. This is simply a non sequitur and, inter alia, excuses problems that can-and should-be confronted and assessed in the search for feasible alternatives. More crucially, Hayek denies that catallaxies possess emergent properties:

Absent from Hayek's image of capitalism as an unimaginably complex mass of individuals responding to one another through markets is any notion of major social structures [...] While modern societies and advanced economies are indeed catallaxies, they are also systems with grand structures.

(Sayer 1995:77-8)

It is therefore unsurprising that the ontological erasure of relatively enduring social structures leads to an emphasis on 'the market' as a sphere of freedom. Yet a market encompasses not simply commodity exchanges and associated transfers of money, but also enduring organised practices that facilitate such exchanges on a regular basis. It is worth briefly discussing the different types of market and the multiple meanings of 'market'.

\section{The nature of 'the market'}

Essentially, makets differ according to the way in which transactions are organised, particularly with regard to pricing. 'Spot markets' are those in which prices are flexible and relationships between actors ephemeral. Spot markets approximate economic models. Yet most real markets do not fit this type of market. Instead, fixed prices provide a stable environment for calculating costs and organising production and distribution. Economic models tend to assume the universality of 'arm's-length contracting', whereby little information other than price is provided and buyer-supplier relationships are minimal. 'Relational contracting', by contrast, involves the sharing of information, the careful building of trust and collaboration between buyer and seller, before and after the transaction. However, neo-liberals wrongly contend that markets work best 'on the spot', at arm's length, and thus 
discourage information sharing. Hayek et al. overestimate the sufficiency of price as a source of information for buyers and sellers in markets. Prior to commodity exchange, non-price information normally has to be exchanged and is usually provided at no extra cost to the buyer.

The New Right is well known for its trumpeting of the 'free' market, in which all that exists (or, rather, matters) are spontaneous exchanges between individuals who have something to sell. The operation of the state is thus regarded as disrupting this smooth-running, spontaneous gathering of free individuals. 'Yet far from being an unnecessary interference, the state is a normal feature of real markets, as a precondition of their existence. Markets depend on the state for regulation, protection of property rights, and the currency' (Sayer 1995:87). We will return to the subject of state regulation in more detail shortly. Suffice it to say, markets are not 'free', since their regulation does not benefit all. There are enduring structured power imbalances. However, Sayer points out that the conceptual slides endemic to employment of 'the market' are a feature of both lay and academic uses and are found in right/left-wing, liberal and economic theory. The Right proffer idealised models of markets as descriptions of de facto markets; the Left avoids any rigorous scrutiny of their properties. Sayer argues that concepts of markets differ according to: (a) their level of abstraction; (b) their inclusiveness; (c) whether they are couched within a 'market optic' or a 'production optic'; and (d) whether they refer to real or imaginary markets.

Real markets may be conceptualised at different levels of abstraction. One can talk about the local fruit-and-vegetable market concretely (who the sellers and buyers are, what is sold, and so on) or more abstractly, that is, in terms of the exchange of commodities and property rights for money or as a mode of coordination of the division of labour. At the same time, concepts of markets also differ in inclusiveness. Markets may be defined narrowly in terms of routinised buying and selling, or inclusively to cover the production and consumption of exchanged goods and the particular property relations involved. Restricted concepts exclude major contextual influences that explain behaviour. As Sayer puts it, '[t]he dynamism of capitalist economies is not simply a consequence of markets in the restricted sense, but of capital, obliged to accumulate in order to survive, and liberated from the ties which bind petty commodity producers' (1995:99). What is included on the Left is determined by a 'production optic', in which markets are marginalised. For the Right, what is included is determined by a 'market optic', whereby production is conflated with exchange. For our purposes, we are concerned with the 'market optic' of the Right. The market optic ignores production and its social relations. Indeed, in mainstream economics, the whole economy becomes the market (in the singular) and almost invariably counterposed to the state. The salient point here is that markets are not an alternative to production, firms or hierarchies (Sayer 1995:101); rather, they are a mode of coordination of the division of labour.

Furthermore, one can distinguish literal concepts that refer to real markets from those that refer to imaginary ones, and also from those that use market 
metaphors that have limited similarity to real markets. As Sayer argues, it is not the level of abstraction used in metaphorical approaches that is important; rather, it is their quality. Indeed, what is often lost is the social relations that underpin real markets.

\section{The transcendental argument}

Transcendentally, the neo-liberal social ontology cannot be sustained: market exchange requires state involvement. The corollary is that the existence of schooling is equally necessary. Given that the market is not 'free', and is necessarily subject to some form of institutional regulation, then

deregulated governance of education loses its justification, and the [neo-liberal] project loses its rationale even on its own terms [...] If this line of reasoning can be sustained when elaborated, it would provide a transcendental argument against the existence of principles of free-market exchange in the governance and distribution of education [...] Furthermore, if neo-liberal principles can be shown to be incompatible with the governance of that social practice without whose alignment no vision for the ordering of society can be realised, then the vision itself is called into question, not only on grounds of equity [...] but on grounds of coherence.

(Jonathan 1997:25-6)

There are two distinct issues to consider here. Firstly, there is the transcendental argument that markets-or Hayek's catallaxy-are regulated by institutions that are irreducible to individuals. Secondly, there is Jonathan's argument that the very institutions that underpin market relationships themselves require an educated workforce, in turn negating the neo-liberal project of subjecting the education system to market disciplinary mechanisms. Put simply, the rationale behind the neoliberal marketisation of the education system ultimately precludes the possibility of market activity. Moreover, neo-liberals themselves are unable to avoid the fact that the education system is state run and did not appear out of thin air. The argument for reconcilability is centred on the short-term need for the state to establish the conditions for a market-based education system. Yet the fact that the state has to regulate belies the neo-liberals' atomistic social ontology that is central to the argument for state non-intervention. The fact that the neo-liberal elements of the 1988 Education Reform Act deny the need for state intervention has serious implications for headteachers and their staff in terms of what is to be taught, how it is to be taught and under what conditions of service (inter alia demanding more for less as schools become subject to the discipline of quasi-market mechanisms).

Crucially, however, the devolution of control to individual schools contradicted the neo-liberal corpus since such devolution was done at the behest of central government. Any argument which claims that such centralised control was intended to be ephemeral, a necessary prelude to complete deregulation, 
simply conceals the contradiction: the need for state control remains while we have an education system. The Hayekian approach disclaims the need for any form of planning, partly because of its state socialist connotations. Consequently, Local Education Authority (LEA) plans for limiting the number of children per school were dismissed out of hand and instead replaced by Local Management of Schools (LMS) funding arrangements, whereby schools were funded on a per capita basis and empowered to recruit as many pupils as practicable via open enrolment. But markets can never be a complete alternative to planning and hierarchy. The Hillgate Group's idea of providing vouchers for parents, if implemented on a wide scale, would itself have required significant planning. Moreover, such planning would have been expensive and not as efficient as the LEA system.

\section{Statistical methods, positivism and ideological commitment}

The above section has provided the transcendental grounds for the claim that the neo-liberal rationale behind the quasi-marketisation of the education system is untenable. In so doing, it has also elaborated the variety of definitions of 'the market' and how the 'market optic' of the neo-liberals denies the irreducibility of social structure. The charge of ideological commitment derives from the concealment of the transcendental necessity of sui generis structures that delimit agential action. In other words, the implicit denial of structural properties enables SER proponents and New Labour to assume that all schools can perform well independently of contextual constraints, in turn creating the work overload and stress that has been reported among the teaching profession. As Scott puts it, '[w] hat is at issue in short is that a method from within a positivist/empiricist framework [...] cannot help but provide support for an agenda which emphasizes control, prediction and the rejection of a holistic view of education' (2000:70). The argument of this section is that the statistical methods and the generic positivism of SER lend themselves to individualistic social philosophies and policies. Indeed, as Thrupp (2001) rightly argues, critics of SER are not concerned with the technical issues in statistical modelling: the issue is whether modelling is able to capture the school processes it is expected to measure. The fact that modelling lacks explanatory power and cannot measure such processes should encourage SE statisticians and users of such statistics to reassess their role as educational researchers and reflect upon the untrammelled ease with which New Right policies appropriate their findings.

As we have seen in the introduction, Goldstein and Woodhouse are concerned about the failure of some critics to understand fully the nature of quantitative techniques. They argue that the power of multi-level modelling can only be realized once 'quality' data have been obtained. Yet we are not told which data and why? The debate is (again) played out at the level of methodology. SE researchers need to move beyond the level of methodology and engage with the priority of ontology Any methodology presupposes a social ontology, implicitly or explicitly. Thrupp 
(2001) notes that 'SER's generally offhand approach to its critics may be especially unfortunate if proponents and critics of SER are often talking past each other as a result of different epistemological commitments as Archer (1999) has argued'. This is indubitable. However, the principal argument of my article concerned ontology, that is, the secreted social ontology of positivist/statistical methods and its contingent congruence with neo-liberalism.

For Goldstein and Woodhouse, however,

Perhaps the most extreme criticism of the use of [mathematical] models comes from Archer, who mounts a general attack on 'positivism'. The difficulty with this critique is that it is very difficult to recognize any real researchers as practising positivists-at least according to Archer's definition. For example, he asserts that positivism is unable to take account of subtle variations of social relationships within institutions over time, yet there are many studies which do model changing relationships of various kinds over time-the main problem being with the availability of the data rather than with the technical procedures required to do the modelling.

$(2000: 359)$

The last comment is instructive, since the authors remain firmly wedded to mathematical modelling. They do not acknowledge that precisely because they remain wedded to mathematical modelling they are positivists: mathematical modelling cannot take account of subtle variations of social relationships over time. But let's be clear about what we mean by positivism. Positivism is a theory of the nature and limits of knowledge. Bhaskar describes it as follows:

Particular knowledge is of events sensed in perception; general knowledge is of the patterns such events show in space and over time, which, if it is to be possible, must be constant [...] Sense-perception exhausts the possible objects of knowledge [...] Positivism is a theory of knowledge. But any theory of knowledge presupposes an ontology [...] Thus the Humean theory, which forms the lynchpin of the positivist system, presupposes an ontology of closed systems and atomistic events [...] Moreover any theory of knowledge presupposes a sociology in the sense that it must be assumed, implicitly if not explicitly, that the nature of human beings and the institutions they reproduce or transform is such that such knowledge could be produced. Thus the Humean theory presupposes a conception of people as passive sensors of given facts and recorders of their given constant conjunctions, which has the corollary that knowledge can always be analysed in a purely individualistic way.

$(1989: 49-50)$

Bhaskar then argues that it is in the resulting inconsistent system that positivism's tremendous versatility and flexibility as an ideology lies. It functions as an ideology for social practices other than science 'by encouraging, by injunction or resonance, 
certain substantive conceptions of the nature of nature, society, persons and their interconnections' (1989:50).

Indeed, as we shall see in a moment, Goldstein and Woodhouse want to incorporate-inconsistently-the fact that schools function within a social and political system, and at the same time retain the primacy of statistical modelling. Ultimately, then, this means that they cannot avoid the denial of social reality qua structured and open system that is intrinsic to mathematical modelling. In brief, there are two conditions that must be met for a closed system to exist. Firstly, there is the intrinsic condition for closure; that is, there must be no change or qualitative variation in the object possessing causal powers if mechanisms are to operate consistently. Secondly, the relationship between the causal mechanism and those of its external conditions must be constant if the outcome is to be regular (the extrinsic condition for closure). As Sayer (1992) points out, the intrinsic condition for closure is ignored even if the extrinsic one is acknowledged. Moreover,

[t]he presence of uninterpreted constants, parameters or coefficients in many models bears witness to the inadequacy of their attempts to produce a correspondence between mathematical and causal order. If they cannot be interpreted as 'standing for' a particular process or characteristic they may more justifiably be described as 'fudge factors' in that their only function is to conceal the inadequacies of the model by providing a means of fitting it to any data set. (With enough parameters, any model can be fitted to any data.) [...] Modellers may not be aware of it, but the inclusion of parameters whose values vary from case to case provides a retrospective but uninterpretable way of allowing for the non-satisfaction of the intrinsic and extrinsic conditions for closure and the mis-specification of causal structure.

(Sayer 1992:184-5)

The transcendentally false assumption that social reality is a closed system is congruent with the OFSTED inspection regime, which is underpinned by SER. OFSTED assumes that learning outcomes can be linked directly and unambiguously to inputs (viz. teaching). Indeed, the tacit OFSTED assumption here is that causal factors are independent, universal and additive; that is, they do not interfere with each other and are uninfluenced by their contexts. The ideological import is palpable: teachers are blamed for pupil 'failure' (in other words, poor examination results). Furthermore, the key determinants (later reworked as key 'factors') that in OFSTED's view constitute 'effective' schools are culled at the level of observable events and in positivist fashion there is no attempt to differentiate between contingency and necessity Indeed, the (eleven) factors are viewed as correlates of effective schools. The idea that there may be a contingent relation between successful learning and strong leadership cannot be entertained. Here, then, we return to the perennial problem of spurious correlations that haunts the use of statistics because of its inability to distinguish accidental from necessary relations. Thus, for Hopkins, "[t]he so-called "effectiveness 
correlates" however sophisticatedly defined are no substitute for models or theories of how schools function. Without this knowledge it is difficult to see how the [SE] field can progress' (1996:30).

Again, the main problem is that statistical modelling cannot deal with components that are not qualitatively invariant (for example, children and teachers) or where they interact causally with one another, or where emergent powers rise or are dissolved through combinations and separations. As Sayer succinctly puts it, '[a]ttempting to explain the effects of an object which has emergent powers in terms of the relative contribution of its constituents is like attributing a certain percentage of behaviour of water to hydrogen effects and the rest to oxygen effects!' (1992:181). Thus, we would not explain why students attend lectures in terms of attributing a certain percentage of their behaviour to lecturer effects and the rest to student effects. Instead, we employ such explanatory concepts as social structure-in this case, the irreducible emergent structural property of lecturer/ student together with its wider structural embedding (university, polity and economy, and the necessary irreducible relations between them). We can count how many students turn up to lectures, but this does not tell us why. Similarly, SER may tell us how many students from working-class backgrounds gain $A^{*}$ - $\mathrm{C}$ GCSE passes but it does not tell us how and why. And although SER may also tell us that certain schools achieve better results for their working-class students, thereby indicating their 'value-addedness', it does not tell us why. This explains why such results become so easily appropriated by New Right government(s), since it is a short step to argue that all schools can achieve high levels of attainment, irrespective of social background. Without adequate explanation (or even attempts at explanation), SE data are ever open to political manipulation. One might reasonably expect an exploration of the material limits to the crude indicators of effectiveness currently imposed. Statistical techniques do not exist in abstract isolation: the socio-political context must always be taken into account, theoretically and ethically-and not as a mere afterthought exemplified by the belated recognition of the importance of social class, which is then statistically controlled for (Archer 1999b).

Ironically, as Goldstein and Woodhouse call for more sophisticated models and 'data', Sayer (1992) argues that the value of statistics is depreciated as our knowledge of causal mechanisms becomes more complete. However, he does argue that the usefulness of statistical methods depends crucially upon the type of objects to which they are applied and the type of research design in which they are employed. In a nutshell, an evaluation of the possibilities of statistical analysis requires a non-statistical examination of the objects of interest: such an examination is conspicuously absent in the existing SE research concerned with mathematical modelling. A common criticism of statistical analyses of relationships among variables is that they tend to abstract from qualitative change in their key objects and from changes in context; often the two are linked and internally related (Sayer 1992:198). By way of an example, Sayer cites industrial change as an area of study in which students have for many years abstracted from the continually changing interdependence between the qualitative nature 
of particular industries and the competitive environment in which they operate, as if the external variables were only externally related and as if the economic environment were just a passive backcloth to the action. This type of analysis has also characterised SE and School Improvement (SI) research. As Goldstein and Woodhouse note:

Schools function within a social and political system which has its own structures and processes, whether these be one of inter-school competition or those determined by externally imposed constraints of curriculum or resource. Despite the recognition of this by many within SE and SI [...] there seems little in the research itself that seriously attempts to address this problem. While SE research has gone some way towards modelling withinschool complexities, it has made almost no attempt to contextualise schools within the wider environment. To do so, of course, would involve political as well as social and cultural considerations and it is doubtful whether this would be welcome to government.

Here we have, on the one hand, a welcome discussion of the importance of the structures and processes that shape what goes on in schools and the recognition of the government's likely disapprobation of research that incorporates the latter, yet, on the other hand, the need for contextualisation is reductively couched in terms of modelling. There is a crucial recognition of the need to contextualise the environment in which schools function, yet immediately we are returned to the familiar territory of mathematical modelling. There is no discussion of the materiality of political and social systems, and of the necessary internal relation between schools, the state and the economy, and how the economy cannot sensibly be statistically represented. Statistically minded SE researchers should take on board the fact that mathematical models assume a closed system (see above). People and their social environments are not externally related and susceptible to treatment as Variables'.

Finally, I wish to reiterate the contingent relationship that exists between statistical methods and the New Right in the context of education. As I have already argued, Goldstein and Woodhouse are quite right to insist that statistical methods have no in-built requirement for a particular managerial structure. However, such methods do not exist in abstract isolation. As Thrupp (2001) rightly notes, the in-house concerns of SE proponents do not run as deep as those of their critics because they see the problem mostly as a matter of encouraging a more satisfactory use of their findings by politicians rather than acknowledging the current managerialist climate. Goldstein and Woodhouse argue that much of what we know about the effects of class is derived from careful statistical modelling. Yet the crucial point is that 'careful statistical modelling' can never explain what is registered statistically. One must be careful not to elide explanation and effects. Indeed, it must be remembered that managerialist structures have been imposed and underpinned by the quantitative data supplied by SE researchers. Providing 
statistical 'evidence' of the effects of class does not tell us whether class itself places limits on educational achievement. An examination of this question should involve rigorous analysis of the nature, dynamics and causal properties of class. This is why the atheoretical nature of statistics readily lends itself to neo-liberal appropriation. While Goldstein and Woodhouse et al. explicitly discuss the issue of class, statistical methods cannot adequately incorporate it and thus any statistical findings should only be used as a tentative starting point. ${ }^{3}$

\section{Lack of theorising within the SE movement}

SE research has long been taken to task for lacking a theoretical base; indeed, this criticism is now accepted by SE proponents. Lauder et al. (1998) rightly point out that the early SE literature was predicated upon notions of ethos and climate in order to lay claim to a 'theoretical' basis for its research. Goldstein and Woodhouse acknowledge this point; however, instructively they also argue that

[i]t is not incumbent upon every research endeavour to provide a strong theoretical basis of the kind that allows interesting predictions and shapes our interpretation of the world being studied. There is, for example, often an important period during which empirical evidence needs to be accumulated before coherent theories can be developed. Naturally, such empirical accumulation makes particular theoretical assumptions about the phenomena it studies, but these can be general ones already in use rather than specific ones that attach exclusively to the particular field of enquiry [...] The choice of framework will itself determine the nature of any inferences which are drawn, and different frameworks can lead to real or apparent conflicts. It is important to appreciate this, since there is a notable lack in the current school effectiveness literature of serious attempts to expose underlying assumptions that the research is making.

$(2000: 360)$

The above is contradictory and confusing. Firstly, Goldstein and Woodhouse conceive of theory, in positivist fashion, in terms of prediction. For predictions give us grounds for expecting something to happen, while causal explanations tell us what makes things happen. Crucially, causal explanations can only serve as grounds for reliable predictions under special conditions-and such conditions are not generally found in social science. For social realists theory is about (fallible) explanation of matters social. Prediction and explanation are mutually exclusive: there is no 'middle ground'.

Secondly, the authors argue that it is not incumbent upon every researcher to provide a strong theoretical basis yet acknowledge at the same time that empirical accumulation makes particular theoretical assumptions. The logic is far from impeccable here. I would suggest that the tension above derives from the atheoretical nature of statistics, whose non-explanatory make-up resonates with 
individualist theories, which Goldstein and Woodhouse want to avoid. However, it is argued, rightly, that the choice of framework determines the nature of any inferences that are drawn. In other words, while in any field of study the nature of what exists cannot be unrelated to how it is studied, what is held to exist shapes considerations about how it should be explained. As Archer (1998) rightly argues, social ontology plays a regulative role vis-à-vis the explanatory methodology for the reason that it conceptualises social reality in certain terms. Conversely, regulation is mutual, since what is held to exist cannot remain immune from what does exist. As Archer puts it,'[s]uch consistency is a general requirement and it usually requires continuous two-way adjustment between ontology and methodology to achieve and sustain it as such' (1998:17). In the case of Goldstein and Woodhouse, the nature of social reality has led to a re-examination of previous assumptions, in particular the incorporation of social class and the acknowledgement of socio-political systems. However, the fact remains that statistical methods retain their primacy, thereby undercutting the ontological basis of the (belated) incorporation of social class.

Archer (1998) argues that the constituent elements of social theorising are threefold, that none is dispensable and that each exerts a regulatory role on the other, as follows:

$$
\text { social ontology } \rightarrow \text { explanatory methodology } \rightarrow \text { practical social theory }
$$

Statistical methods and modelling dispense with all three elements, yet in practice they cannot avoid making implicit ontological assumptions. However, this does not mean that any social ontology can be added on: precisely because statistical methods cannot deal in any meaningful sense with the stratified nature of social reality means that individualistic theories or ontological underpinnings are its 'natural' territory. SE statisticians need to recognise the severe explanatory limits of their tools and to put their sociopolitical (ontological) cards on the table, so to speak.

\section{Concluding remarks}

This chapter has reiterated the charge of ideological commitment against SE statisticians. The warrant to do so derives from the contingent compatibility between the unstructured, flat social ontology of neo-liberalism, which underpinned the restructuring of education in England and Wales, and the inability of statistical methods to acknowledge the stratified nature of social reality. It is because SE statisticians continue to deny the charge of association with the New Right that considerable time has been devoted to spelling out the nature of neoliberalism, its transcendental untenability and the transcendental social realist alternative of ontological stratification. It is indeed welcome that SE mathematical modellers are attempting to distance themselves from government influence. However, they have yet to acknowledge the fact that statistical data are derived from sociopolitical contexts that their models cannot explain, which in turn makes 
the data susceptible to abuse by government. I would suggest that the primacy given to modelling and statistics in some SER quarters be greatly attenuated in favour of theorising about the nature of schooling and society and, concomitantly, the material limits to 'improvement'.

\section{Notes}

1 It is important to explain the realist social ontology adopted in this chapter at the outset, for it provides the basis for the charge of ideological commitment made against neo-liberalism and SER. In brief, transcendental realism is committed to what social reality must be like in order to make analysis of it intelligible. In other words, it makes claims as to its necessary conditions that make it a possible object of knowledge. Transcendental social realism does not make claims as to which structures constitute social reality, but that it is structured, that is possesses sui generis enduring relations. The unobservable nature of irreducible social relations (for example, between teacher and pupil) lies at the heart of the realist conception of social structure. Structure is viewed neither as an aggregate of individuals nor as an observable regular pattern of events. It is not held to be independent of agency; rather, it is maintained that structure is an emergent property that is sui generis real by virtue of its relational nature. A teacher presupposes a pupil (or pupils), a head presupposes teachers, a governing body presupposes teachers, pupils, heads and administrative staff, and so on. Thus, we are talking about internal relations between roles, which are ontologically distinct from the individual people who fill them and whom they causally affect. The teacherpupil internal necessary relation is an irreducible emergent property because the powers deposited within the roles modify the powers of the individuals as individuals. A lecturer cannot self-award a first-class honours degree just as a student cannot revoke the decision of a degree classification board: such powers do not reside in the properties of individuals but reside in the social relations that presuppose such individuals for their enduring efficacy (and hence mediation) (Archer 1999a).

2 This applies equally to Mortimore and Sammons, who, in a response to charges of ideological commitment, have argued: ' $\mathrm{h}] \mathrm{ow}$ can anyone who understands research methodology [...] make such an unfair accusation?' (1997:185). What such SER exponents consistently eschew is an exploration and/or defence of the implicit social ontology that ineluctably underpins their methodological commitments. See Archer (1999b) for a fuller discussion.

3 In relation to social background and educational performance, Sayer notes that one may be tempted to interpret the subject from the start as involving questions about possible generalisations and quantifiable formal relations:

'How does educational performance vary with social background?' As soon as this question is posed in this way we tend to opt without further ado for a quantitative analysis. From then, the next major decision involves choosing 'variables', 'factors' or 'indicators' for which there are data [...] But it is also possible, though more difficult, to think of such issues causally, in terms of the processes and mediations by which membership of a particular social class, a particular type of educational institution and particular economic circumstances affects attitudes to education, etc. This could be incorporated with empirical study of concrete instances of the relationship.

(Sayer 1992:202) 


\section{References}

Angus, L. (1993) 'The sociology of school effectiveness', British fournal of Sociology of Education 14:333-45.

Archer, M. (1995) Realist Social Theory: The Morphogenetic Approach, Cambridge: Cambridge University Press.

--(1998) 'Social theory and the analysis of society', in T.May and M.Williams (eds) Knowing the Social World, Buckingham: Open University Press.

Ball, S.J. (1990) Politics and Policy Making in Education, London: Routledge.

Bhaskar, R. (1989) Reclaiming Reality: A Critical Introduction to Contemporary Philosophy, London: Verso.

Clarke, J., Gewirtz, S. and McLaughlin, E. (2000) 'Reinventing the welfare state', in J. Clarke, S.Gewirtz and E.McLaughlin (eds) New Managerialism, New Welfare?, London: Sage.

Dale, R. (1992) 'Recovering from a pyrrhic victory? Quality, relevance and impact in the sociology of education', in M.Arnot and L.Barton (eds) Voicing Concerns: Sociological Perspectives on Contemporary Educational Reforms, Wallingford: Triangle Books.

DuGay, P. (2000) 'Entrepreneurial governance and public management: the antibureaucrats', in J.Clarke, S.Gewirtz and E.McLaughlin (eds) New Managerialism, New Welfare?, London: Sage.

Fergusson, R. (2000) 'Modernizing managerialism in education', in J.Clarke, S.Gewirtz and E.McClaughlin (eds) New Managerialism, New Welfare?, London: Sage.

Freeden, M. (1999) 'The ideology of New Labour', The Political Quarterly 70:42-51.

Gamble, A. (1988) The Free Economy and the Strong State, London: Macmillan.

Gewirtz, S., Ball, S.J. and Bowe, R. (1995) Markets, Choice and Equity in Education, Buckingham: Open University Press.

Gillborn, D. and Youdell, D. (2000) Rationing Education: Policy, Practice, Reform and Equity, Buckingham: Open University Press.

Goldstein, H. and Woodhouse, G. (2000) 'School effectiveness research and educational policy', Oxford Review of Education 26:353-63.

Hill, D. (1999) New Labour and Education: Policy, Ideology and the Third Way, London: Tufnell Press.

Hopkins, D. (1996) 'Towards a theory for school improvement', in J.Gray, D.Reynolds, C.Fitz-Gibbon and D.Jeeson (eds) Merging Traditions: The Future of Research on School Effectiveness and School Improvement, London: Cassell.

Jonathan, R. (1997) Illusory Freedoms: Liberalism, Education and the Market, Oxford: Blackwell.

Lauder, H., Jamieson, I. and Wikeley, F. (1998) 'Models of effective schools: limits and capabilities', in R.Slee, S.Tomlinson and G.Weiner (eds) School Effectiveness for Whom?, London: Falmer Press.

Morley, L. and Rassool, N. (1999) School Effectiveness: Fracturing the Discourse, London: Falmer Press.

Mortimore, P. and Sammons, P (1997) 'Endpiece: a welcome and a riposte to critics', in J. White and M.Barber (eds) Perspectives on School Effectiveness and School Improvement, London: Institute of Education.

Olssen, M. (2000) 'Ethical liberalism, education and the "New Right"', fournal of Education Policy 15:481-508.

Powell, M. (1999) 'Conclusion', in M. Powell (ed.) New Labour, New Welfare State? The 'Third Way' in British Social Policy, Bristol: Policy Press. 
Reynolds, D. (1998) 'The school effectiveness mission has only just begun', Times Educational Supplement, 20 February, 20.

Sayer, A. (1992) Method in Social Science: A Realist Approach, London: Routledge.

--(1995) Radical Political Economy: A Critique, Oxford: Blackwell.

Scott, D. (2000) Realism and Educational Research: New Perspectives and Possibilities, London: Routledge.

Teddlie, C. and Reynolds, D. (2000) 'Responses to the criticisms of school effectiveness research', paper presented at AERA Annual Meeting, New Orleans, 24-28 April.

Teddlie, C., Reynolds, D. and Sammons, P. (2000) 'The methodology and scientific properties of school effectiveness research', in C.Teddlie and D.Reynolds (eds) International Handbook of School Effectiveness Research, London: Falmer Press.

Thrupp, M. (1999) Schools Making a Difference: Let's Be Realistic!, Buckingham: Open University Press.

--(2001) 'Recent school effectiveness counter-critiques: problems and possibilities', British Educational Research Fournal 27(4): 443-57.

Whitty, G., Power, S. and Halpin, D. (1998) Devolution and Choice in Education, Buckingham: Open University Press.

Archer, R. (1999a) 'Structure, agency and the sociology of education: rescuing analytical dualism', British fournal of Sociology of Education 20:5-21.

--(1999b) 'School effectiveness research: an ideological commitment?', Journal of Philosophy of Education 33:253-68.

--(2002) Education Policy and Realist Social Theory: Primary Teachers, Child-Centred Philosophy and The New Managerialism, London: Routledge. 